\title{
湿式化学法による単分散球状単結晶銀粒子の合成
}

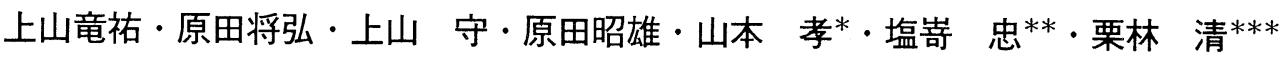 \\ 大研化学工業(株), 536-0011 大阪市城東区放出西 2-7-19 \\ *防衛大学校, 239-0811 横須賀市走水 1-10-20 \\ **奈良先端科学技術大学院大学物質創成科学研究科, 630-0101 奈良県生駒市高山町 8916-5 \\ ***帝京科学大学環境マテリアル学科, 409-0133 山梨県北都留郡上野原町八ッ沢 2525
}

\section{Synthesis of Monodispersed Spherical Single Crystalline Silver Particles by Wet Chemical Process}

\author{
Ryousuke UEYAMA, Masahiro HARADA, Tamotsu UEYAMA, Akio HARADA, Takashi YAMAMOTO*, \\ Tadashi SHIOSAKI** and Kiyoshi KURIBAYASHI ${ }^{* * *}$ \\ Daiken Chemistry Industry Corporation Limited, 2-7-19, Hanaten-nishi, Joto-ku Osaka-shi 536-0011 \\ *Department of Electrical Engineering, National Defense Academy, 1-10-20, Hashirimizu, Yokosuka-shi, Kanagawa 239-0811 \\ **Graduate School of Materials Science, Nara Institute of Science and Technology, 8916-5, Takayama-cho, Ikoma-shi, Nara 630-0101 \\ ***Department of Materials, Teikyo University of Science and Technology, 2525, Yatuzawa, Uenohara-machi, Yamanashi 409-0133
}

\begin{abstract}
Ultrafine silver monodispersed particle were prepared by wet chemical process. To decrease the reduction speed, an important factor in generating monodispersed particles is to control the following three factors: synthesis temperature, concentration of aggregation-relaxing agent added, and concentration of silver nitrate solution. Synthesis of monodispersed spherical Ag particles, used as metal powders for electrode, became possible using the nucleus growth reaction method. This process also allowed the control of the diameter of the powder particles. The silver particles were distributed in a narrow particle diameter range with on average of $0.5 \mu \mathrm{m}$. Transmission electron microscopy (TEM) revealed that single-crystalline silver particles were prepared by the present method. [Received July 16, 1998; Accepted November 6, 1998]
[
\end{abstract}

Key-words : Monodispersed, Spherical particles, Wet chemical process, Multilayer ceramic devices

\section{1. 緒 言}

粒子の粒径や形にほとんど分布がない粒子の一群を単分散粒 子と呼ぶ。単分散粒子の合成法としては，一般的にStober 型1) と呼ばれる金属アルコキシドによる加水分解法による研究 がある、単分散粒子は, 酸化チタン $\left(\mathrm{TiO}_{2}\right)$, 酸化ジルコン $\left(\mathrm{ZrO}_{2}\right)$, 酸化タンタル $\left(\mathrm{Ta}_{2} \mathrm{O}_{5}\right)$, チタン酸ジルコン酸鉛 (PZT), などのセラミックス粒子の研究がほとんどであり電 子セラミックスなどで使用する電極用金属粉についての研究は 比較的少ない2) 8). 電極用金属粉の合成については, 主に化

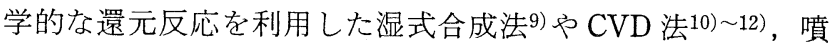
霧熱分解法 ${ }^{13)}$ による研究がある。この内 CVD 法や噴霧熱分解 法などで代表される気相法による金属粉は比較的単分散性に優 れているが製造コストが高いばかりでなく生産性が低く，かつ 核生成と粒成長が同時に起ってしまい粒径制御ができておらず 粒度分布が広くなりやすい欠点がある.

一方, 湿式合成法では凝集力が非常に強いため単分散粒子を 合成することは非常に困難なのが現状であり，工業規模はもち ろん実験レベルでも単分散粒子の合成に関する報告は少ない8).

近年電子機器の小型・薄層化に伴い誘電体層や内部電極の薄 層化が急務になってきた。 その際, 凝集粒子の存在は, 誘電体 層や内部電極の薄層化に伴う層間短絡や断線不良あるいは構造 欠陥の発生の大きな要因になっている。したがって，これらの 層間で起る短絡断線を回避するためには誘電体層や内部電極に 使用する粉末原料としては凝集粒子がなく独立単分散な球状粒 子が必要である.

本研究は, 電子セラミックス分野で多用されている電極材料 として製造コストが安価で大量生産が可能な銀 $(\mathrm{Ag})$ 金属微 粒子の湿式合成法に着目し凝集のない, 独立単分散球状粒子を 合成することを第 1 の目的とし，その生成機構について央験 的に検討した.

\section{2. 実験方法}

本研究では，対象金属として銀（Ag）を検討し，通常の湿 式合成反応装置を用いて合成した。

出発原料は, 室温で固体の工業用として一般に使用されてい る $\mathrm{Ag}$ 金属含有率 $63.5 \%$ の硝酸銀 $\left(\mathrm{AgNO}_{3}\right)$ を用いた。まず, 出発原料である硝酸銀を精製水に溶かし硝酸銀水溶液を得た. このとき, 粒子の凝集を緩和させる目的でアラビアゴムを添加 した，得られた硝酸銀水溶液をヒドラジン $\left(\mathrm{N}_{2} \mathrm{H}_{4}\right)$ で還元し 銀粒子を得た.なお, 銀粒子の粉末回収に当たっては乾燥過程 での再凝集を抑制する目的であらかじめスラリー中に適量の有 機自己組織膜形成剤を添加した. 表 1 に本実験の合成条件を示 す.

合成した銀粒子は，マイクロトラック粒度分布計(日機装製， HRA100型) で分散性を評価した。 また, 合成粒子表面の微細 構造は, 走査型電子顕微鏡 (SEM ; 日本電子製, JSM-6100型) を用いて観察した。結晶性は，透過型電子顕微鏡（TEM；日 本電子製，JEM-2010）により粒子の内部構造を観察するとと もに電子線回折で調べた。 また, 結晶子サイズは X 線回折 (XRD ; 理学電機製, RINT-Ultima+グラファイトモ)クロ メーター)で求めた. 得られた銀粒子の粉体特性はタップ密度, BET 法による比表面積で評価した.

Table 1. Synthesis Condition of Ag Powders

\begin{tabular}{lccc}
\hline & (a) & (b) & (c) \\
\hline $\mathrm{AgNO}_{3}$ concentration $(\mathrm{g} / 1)$ & 80 & $4 \sim 80$ & 2 \\
Synthesize temperature $\left({ }^{\circ} \mathrm{C}\right)$ & $-10 \sim 30$ & 5 & 5 \\
Gum arabic concentration $(\mathrm{g} / 1)$ & 3.75 & $3.75 \sim 11.25$ & 7.5 \\
$\mathrm{NaOH}$ concentration $(\mathrm{g} / 1)$ & 24 & - & - \\
$\mathrm{N}_{2} \mathrm{H}_{4}$ concentration $(\mathrm{g} / 1)$ & - & 27.2 & 27.2 \\
\hline
\end{tabular}




\section{1 単分散粒子の合成}

\section{$3.1 .1 \mathrm{Ag}$ 生成粒子に及ぼす合成温度の影響}

$\mathrm{Ag}$ 生成粒子に及ぼす合成温度の影響については，その前駆 体である酸化銀 $\left(\mathrm{Ag}_{2} \mathrm{O}\right)$ で検討した，その理由としては，本 実験濃度での還元反応では，還元速度が急速であるため，凝集
が極めて激しく必ずしも還元された $\mathrm{Ag}$ 粒子の形態を観察して

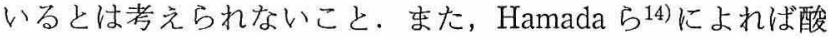
化粒子とその還元粒子との間には粒形状や粒径に一定の関係が あると報告があるためである。

図 1 に各温度で得られた $\mathrm{Ag}_{2} \mathrm{O}$ 粒子の SEM 写真と粒度分布 測定結果を示す。また，合成条件は表 1 (a)に示すとおりであ

a)

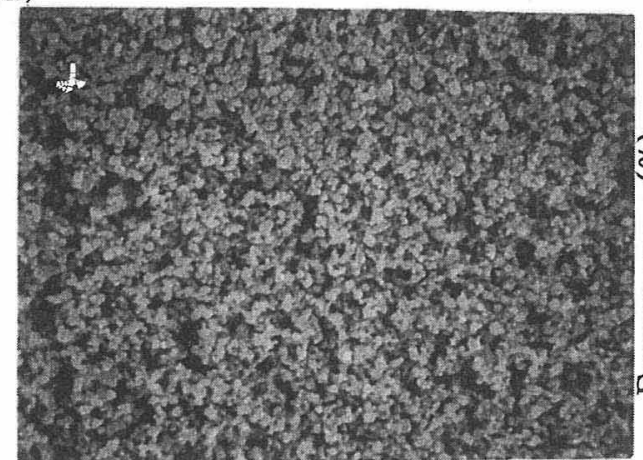

b)

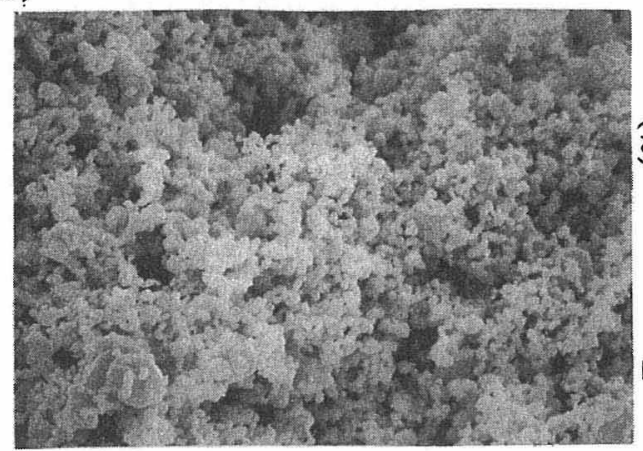

(c)

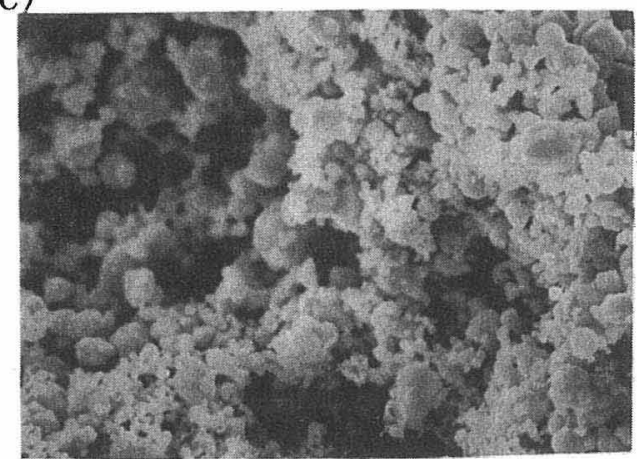

d)

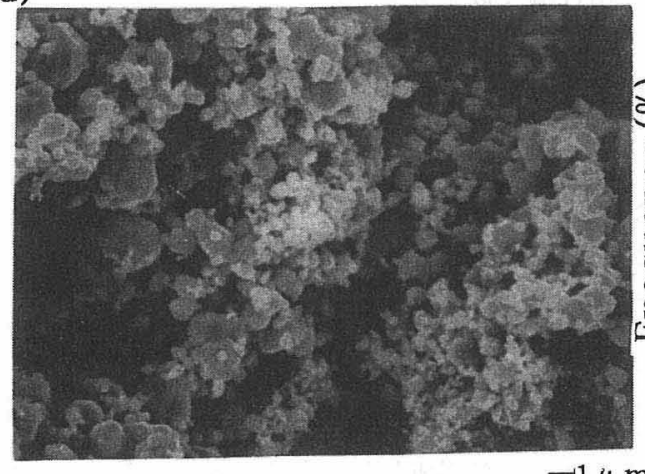

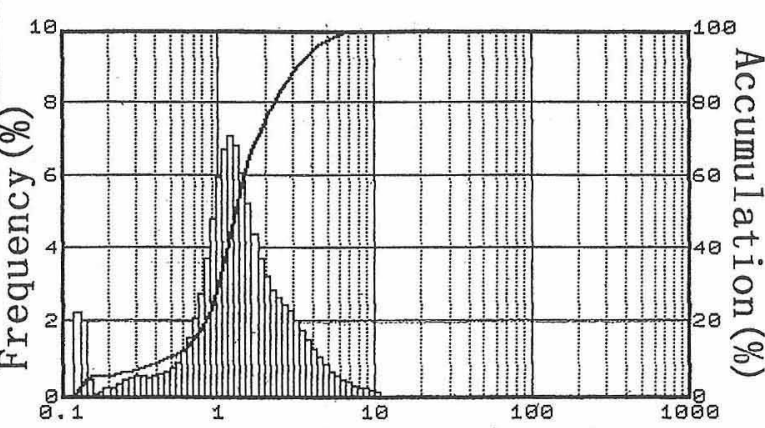

Particle size $(\mu \mathrm{m})$

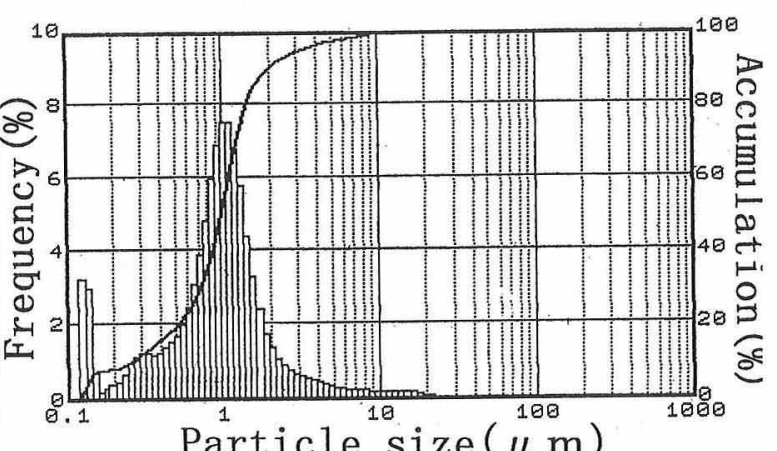

Particle size $(\mu \mathrm{m})$

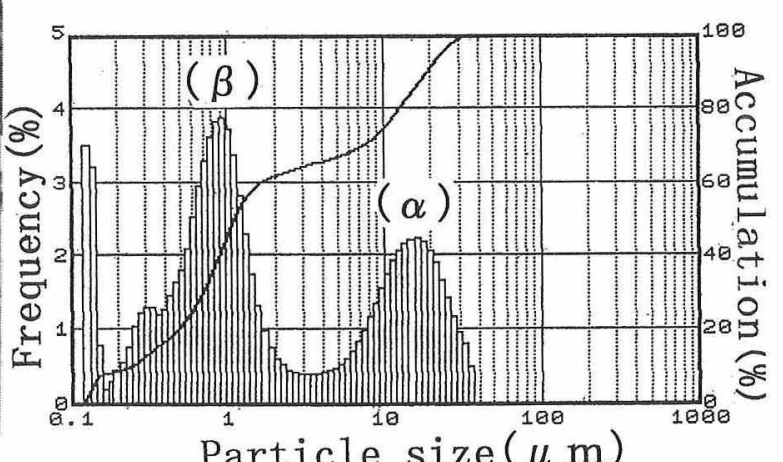

Particle size $(\mu \mathrm{m})$

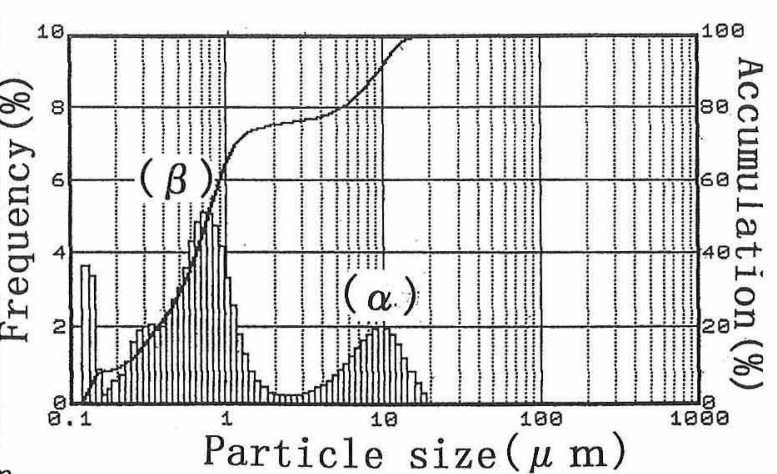

Fig. 1. SEM photograph and a particle size distribution measured by Microtrac laser particle size analyzer with various synthesize temperature.

(a) $30^{\circ} \mathrm{C}$, (b) $10^{\circ} \mathrm{C},\left(\right.$ c) $0^{\circ} \mathrm{C}$, (d) $-10^{\circ} \mathrm{C}$. 
る、合成温度が低温になるに従って $\mathrm{Ag}_{2} \mathrm{O}$ 粒子が大きくなる傾 向があり，合成温度が高温になるに従って合成粒子径は小さく なる傾向がある．これらは，以下のように考えると理解でき る. 前者は, 合成温度が低温になると苛性ソーダによる硝酸銀 を酸化する速度が遅くなるため $\mathrm{Ag}_{2} \mathrm{O}$ 粒子核の生成数が減少す る. その結果，引き続いて生成する $\mathrm{Ag}_{2} \mathrm{O}$ が銀粒子核の積極的 な析出成長に費やされるためであると考えられる。一方, 後者 は, 合成温度が高温になり, 酸化反応の速度が速くなると生成 する $\mathrm{Ag}_{2} \mathrm{O}$ 粒子核の数が増大する。したがって, $\mathrm{Ag}_{2} \mathrm{O}$ 粒子核 への析出成長に費やされる $\mathrm{Ag}_{2} \mathrm{O}$ の絶対量が減少する. その結 果, 合成される $\mathrm{Ag}_{2} \mathrm{O}$ 粒子径が小さくなるものと考えられる. また，図 1 の粒度分布測定では低温になるに従って粒度分布 が二つに分離した．この図中粗大粒子側の頻度ピーク（図中の 記号 $(\alpha)$ ) は，核粒子及び成長過程にある粒子が凝集したも のである.これに対して微粒子側の頻度ピーク（図中の記号 ( $\beta$ ) ) は, 残余の硝酸銀が新たな $\mathrm{Ag}_{2} \mathrm{O}$ 核として生成し，それ が粒成長しているためである。したがって, 低温の $0^{\circ} \mathrm{C}$, $-10^{\circ} \mathrm{C}$ 場合の粒度分布には核発生と粒成長の二つの機構に よって生成した $\mathrm{Ag}_{2} \mathrm{O}$ 粒子が混在していると考えられる.

\section{$3.1 .2 \mathrm{Ag}$ 生成粒子に及ぼす凝集緩和剤の影響}

表 1 (b)に示す条件において, 還元する際の凝集を緩和させ る目的で添加したアラビアゴムが Ag 生成粒子に及ぼす影響を 検討した.

(a)

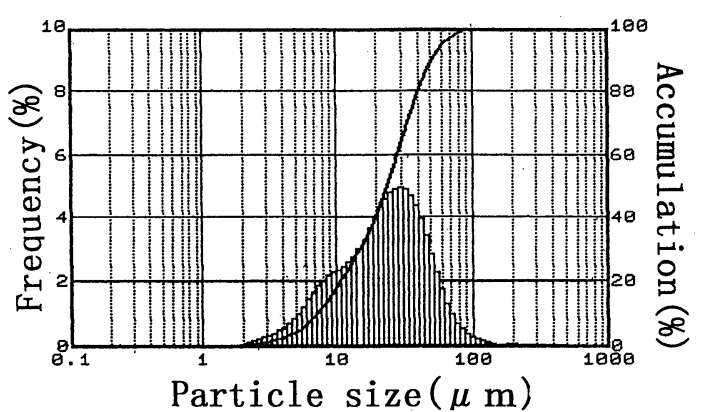

(b)

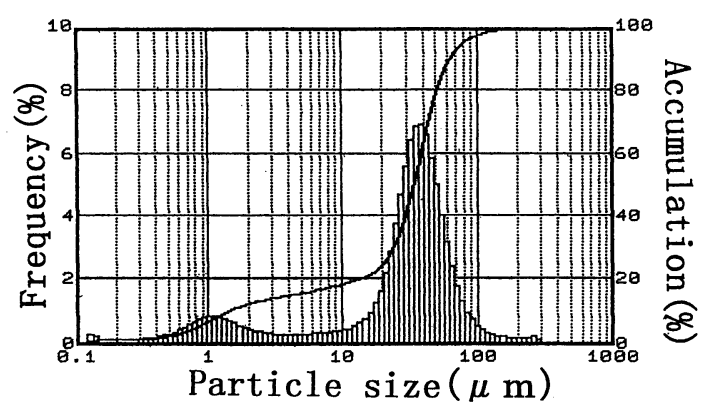

(c)

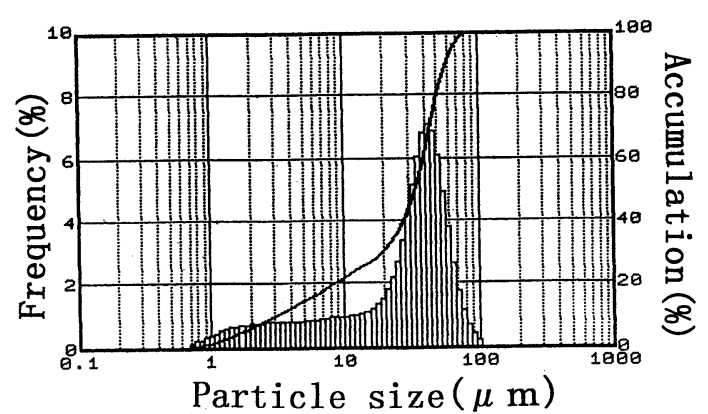

Fig. 2. A particle size distribution measured by Microtrac laser particle size analyzer with various gum arabic concentration. (a) $3.75 \mathrm{~g} / 1$, (b) $7.5 \mathrm{~g} / \mathrm{l}$, (c) $11.25 \mathrm{~g} / 1$.
図 2 に, アラビアゴム添加量を変化させた場合の生成 $\mathrm{Ag}$ 粒 子の粒度分布を示す. アラビアゴム添加量が増加すると粒度分 布が狭くなり分散性が向上した。生成 $\mathrm{Ag}$ 粒子の 1 次粒径は平 均 $30 \mu \mathrm{m}$ でありアラビアゴム添加量によって変化しなかった. また, 過㮃のアラビアゴムの添加は生成した $\mathrm{Ag}$ 粒子の水相か らの沈殿分離を著しく遅くし，このため，乾燥粉末として取り 出すことを非常に困難にした。したがって，本実験では凝集緩 和剂のアラビアゴム添加量を沈殿分離限界の $7.5 \mathrm{~g} / 1$ とした.

\subsubsection{Ag 生成粒子に及ほす硝酸銀濃度の影響}

湿式合成法で $\mathrm{Ag}$ 粒子を生成させるとき, 最も重要な要素と 考えられる合成時の硝酸銀溶液の濃度が $\mathrm{Ag}$ 生成粒子径, 凝集 に及ほす影響について検討した，合成条件は，表 1 (b)に示す とおりである。

図 3 に, 生成した $\mathrm{Ag}$ 粒子の SEM 写真と粒度分布を示す. 硝酸銀の溶液濃度が $40 \mathrm{~g} / 1$ から $4 \mathrm{~g} / 1$ と希薄になるに従って, 生成粒子径が小さくなるとともに凝集粒子が少なくなり単一粒 度分布を示した．これより凝集粒子を生成する理由として硝酸 銀濃度の影響が非常に大きいことが分かった。

\section{$3.2 \mathrm{Ag}$ 粒子の核発生機構と粒成長機構}

湿式合成法において単分散粒子を得る 3 要素として合成温 度, 凝集緩和剤, 硝酸銀濃度の影響について検討した。 その結 果より，単分散粒子の合成には，還元速度が密接に関係してお り低温の合成温度で, 適量の凝集緩和剂を添加し, 硝酸銀濃度 を希薄にすることが重要であることが分かった。

以上より得られた実験結果を踏まえ，単分散粒子の生成法の 基本である LaMer ${ }^{15)}$ の考え方に基づき，希薄な硝酸銀溶液中 での $\mathrm{Ag}$ の核生成及び，生成核粒子の成長という“2 段階成長 法による独立単分散球状 $\mathrm{Ag}$ 粒子の合成方法”を考察する.

図 4 に, LaMer による粒子の生成と成長を模式図的に示す. 溶質を少量ずつ添加すると，一端は溶質濃度は増加するが添加 と同時に還元反応が始まり，それに伴い溶液中の溶質の濃度 は, 短時間で極大值を経て次第に減少し, 最終的に過飽和濃度 に落ち着く.この過程は, 以下のように三つの領域に分類でき る. 反応系に溶質を連続的に添加すると, 溶質濃度は一端は増 加するが，平衡溶解度 $C_{\mathrm{s}}$ を超えたところで溶質はこれ以上溶 解しないので, 反応系の濃度は過飽和状態になる (I 領域). 更に溶質濃度を増加させると $C_{\min }$ で核生成が始むり, 核生成 が始まると溶質が急激に消費されるので溶質濃度は増加が止ま り供給と消費が均一になったところで最大溶質濃度 $C_{\max }$ をと る (II 領域)。核生成が始まったところで溶質の供給を停止す れば溶質濃度は直ちに低下し，過飽和度が低下するので新しい 核の生成は止まる (III 領域). 成長できる臨界核の大きさは 難溶性塩で数十分子程度の結合と言われており合成核は $1 \mathrm{~nm}$ 程度と考えられる.

本実験では，上述の核発生・成長メカニズムを踏をえ合成条 件は表 1 (c)によった.

図 5 (a)，(b)に核発生粒子から段階的に成長させた場合の SEM 写真を示す. SEM 写真から明らかなように初期に成長 した核粒子は成長のみさせることによって, 平均粒径が 0.1 $\mu \mathrm{m}$ から $0.5 \mu \mathrm{m}$ まで変化している. また, $0.5 \mu \mathrm{m}$ まで成長さ せた $\mathrm{Ag}$ 粒子は, 凝集もなく独立単分散球状粒子として成長し ている.

以上の結果，生成核に対する添加 $\mathrm{Ag}$ の還元が $\mathrm{Ag}$ の成長に 費やされた最終成長効率を求めた。まず, SEM 写真より核粒 子の直径を求め, 核の 1 個当たりの重量を(1)式で与える.

(核の重量 $(A))=($ 球の体積 $(V)) \times($ 比重 $(d))(1)$ 核の数 $(C)$ は添加した $\mathrm{Ag}$ の重量 $(B)$ から(2)式で求めら 
(a)

(b)
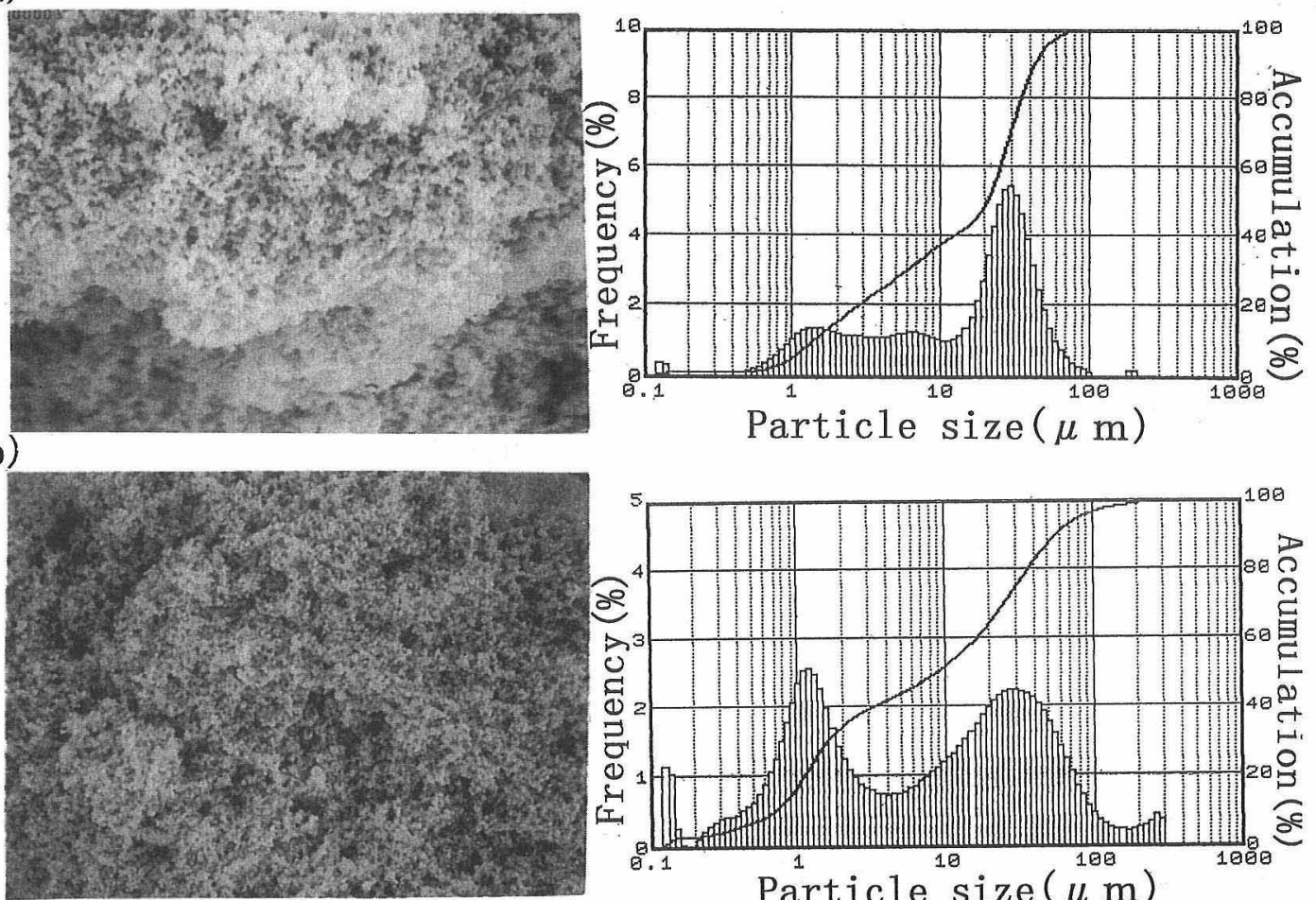

(c)
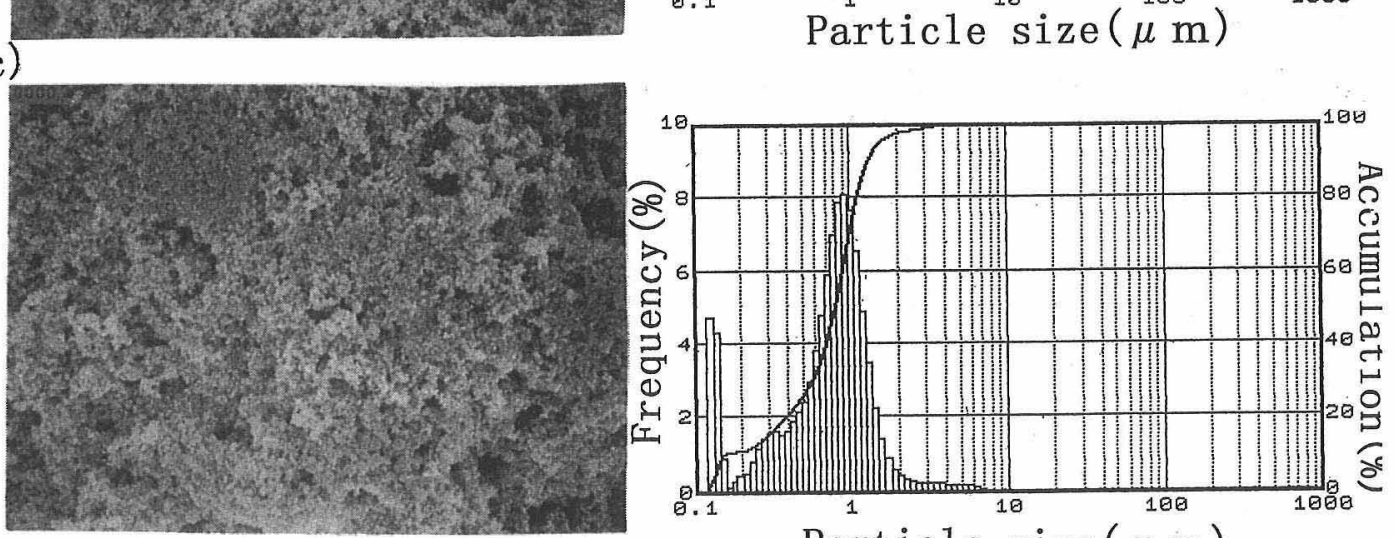

Particle size $(\mu \mathrm{m})$

$-1 \mu \mathrm{m}$

Fig. 3. SEM photograph and a particle size distribution measured by Microtrac laser particle size analyzer with various $\mathrm{AgNO}_{3}$ concentration.

(a) $40 \mathrm{~g} / \mathrm{l}$, (b) $20 \mathrm{~g} / \mathrm{l}$, (c) $4 \mathrm{~g} / \mathrm{l}$.

れる。

$$
C=B / A
$$

また, 同様に SEM 写真より成長 $\mathrm{Ag}$ の直径を求め, その体積 及び $\mathrm{Ag}$ の真密度から成長 $\mathrm{Ag}$ 粒子 1 個当たりの重量を求め た. 成長した $\mathrm{Ag}$ 粒子の数は, 添加した $\mathrm{Ag}$ の重量から逆算し て推定した，成長に費やした $\mathrm{Ag}$ の重量 $(E)$ は，(3)式で求め た.

$$
\begin{aligned}
E & =\{(\text { 成長した体積 })-(\text { 核の体積 })\} \times(\mathrm{Ag} \text { の比重 }) \\
& =(\text { 成長体積 }) \times(\mathrm{Ag} \text { の比重 })
\end{aligned}
$$

以上より，最終的に成長した $\mathrm{Ag}$ 粒子を合成するのに費やした 全 $\mathrm{Ag}$ の重量 $(F)$ は，(4)式で与えられる.

$$
\begin{aligned}
F= & \{\text { 成長した } \mathrm{Ag} 1 \text { 個当たりの重量 }(E)\} \\
& \times \text { (成長 } A g \text { 数 })
\end{aligned}
$$

生成核に対する添加 $\mathrm{Ag}$ の還元が $\mathrm{Ag}$ の成長に費やされた最終 成長効率 $(G)$ は，(5)式で計算できる.

$$
G=(\text { 成長 } \mathrm{Ag} \text { の重量 }) /(\text { 投入 } \mathrm{Ag} \text { の重量) }
$$

これより本研究の実験条件 $(C)$ では, 生成核に対する添加 $\mathrm{Ag}$ の還元が $\mathrm{Ag}$ の成長に費やされた最終成長効率は，87.4\% であった. 以上の考察より添加した $\mathrm{Ag}$ は, 大部分核粒子の成 長に費やされたと考えられる一方, 残りの12.6\%はあらたな核 生成に費やされたものと考えられる。これについては，今後詳 細に検討することが必要である.

添加 $\mathrm{Ag}$ 量と粒径の関係（粒成長）を SEM 観察より求めた 結果を図 6 に示す。図より添加する $\mathrm{Ag}$ の量によって粒径制御 が可能である。

一方，スラリー中から回収した粉末粒子は，多くの場合良く 知られているように凝集粒子となる，この凝集粒子は，スラ リ一中ではたと充独立単分散粒子であっても，粉末として水相 から回収し乾燥する際に起こった再凝集であるう。したがっ て，スラリー状態から乾燥過程で凝集がどのように進むのか確 認するためにスラリーから直接粒度分布を測定し，乾燥粉末の それと比べるとともに，あらかじめスラリーに有機自己組織膜 


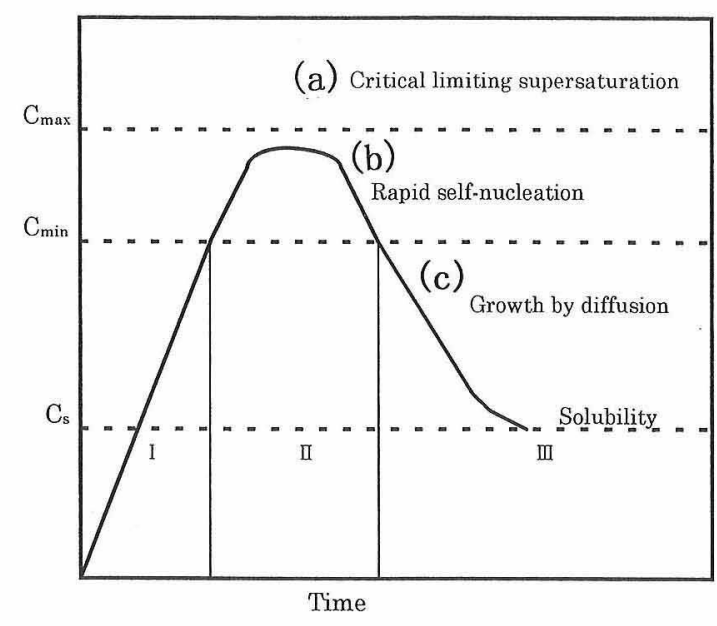

Fig. 4. LaMer's model for the formation of a homodispersed system by controlled homogeneous nucleation and growth.

I : Prenucleation period, II : Nucleation step, III : Growth step.

(a)

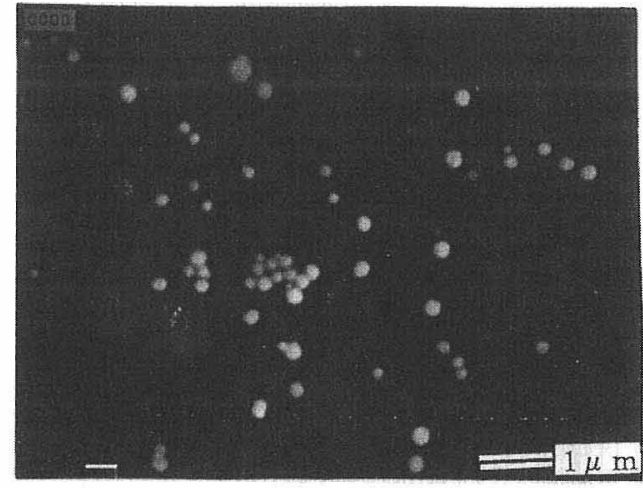

(b)

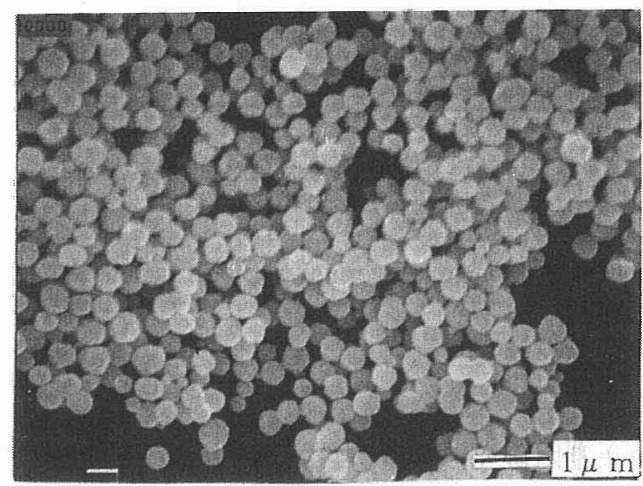

Fig. 5. SEM photograph of nuclear silver particle and grown up silver particle. (a) Nuclear silver particle, (b) grown up silver particle.

形成剂を添加し，これを乾燥して回収した粉末の粒度分布を測 定し凝集の進行の有無を検討した。 その結果, 有機自己組織膜 形成剂を添加してから乾燥し回収した粉末の粒度分布は, スラ リーを用いて直接測定した粒度分布とほぼ一致したが，スラ リーを単純に直接乾燥して得た粉末の粒度分布は著しく粗大粒 子を示した，以上の結果は，有機自己組織膜形成剤を用いるこ とにより乾燥による再凝集を，抑制できることを示している.

核成長反応法によって合成した $\mathrm{Ag}$ 粒子を観察した TEM 写 真と, 電子線回折スポットを図 7 (a), (b)に示す。合成した $\mathrm{Ag}$ 粒子は高い結晶性を示す六角形をしており電子線回折ス

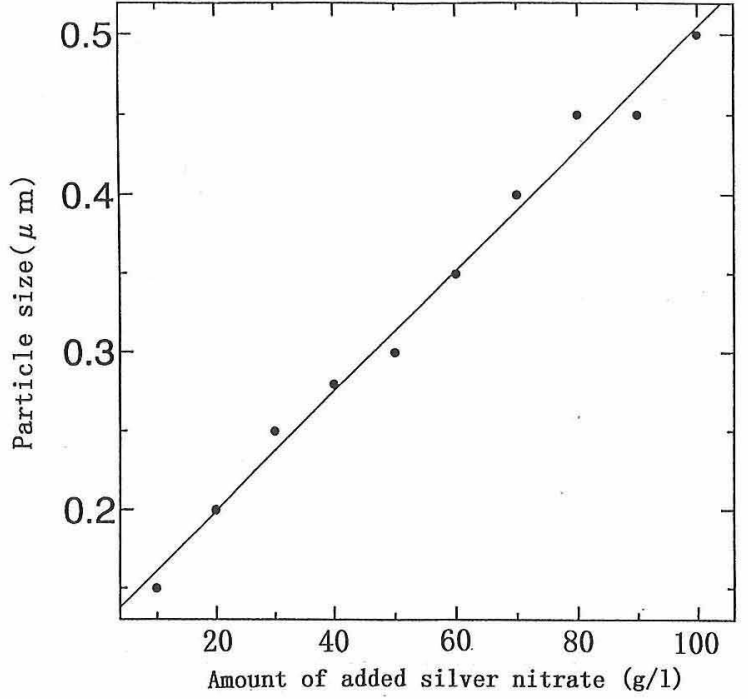

Fig. 6. Relationship between amount of added silver nitrate and particle diameter.

(a)

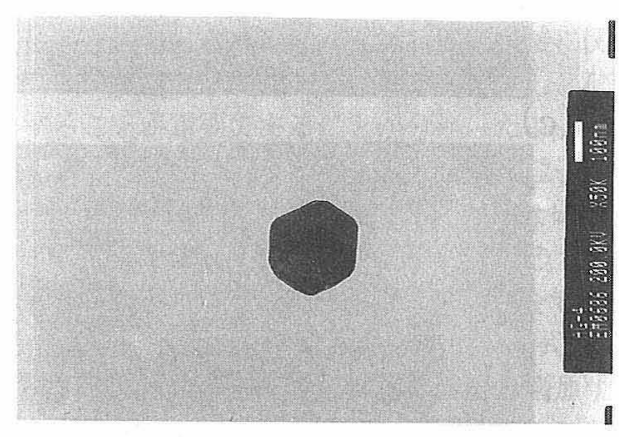

(b)

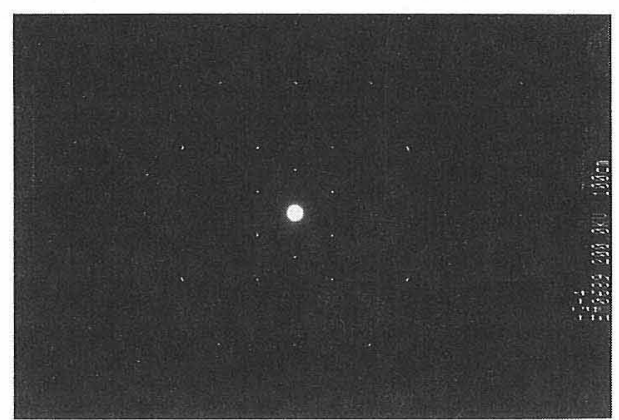

Fig. 7. TEM photograph and electron beam diffraction spot of silver particles. (a) TEM photograph, (b) electron beam diffraction spot.

ポットが明確なことから単結晶状であった。

単結晶状の粒子の生成機構としては, 以下の二つの機構が考

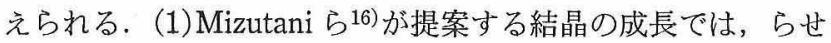
ん転移のテラスやキンクのところに溶質分子が吸着し, 表面拡 散によって移動し結晶に組み込まれる生成機構と(2)Matijevici1)が提案している溶質分子が核の表面のいたるところに吸 着しその結果，2次元の多核層成長が全表面で起こるという生 成機構である。しかし，本実験で生成するような粒子核には (1) の生成機構である転移の存在は考えにくく，(2)の Matijevic ${ }^{17}$ による生成機構の方が妥当であうう，守なわち，本実 験より得られた単結晶状粉末粒子も同様な付着反応様式で成長 することで核を中心に緻密な成長が進み，気孔やボイドのない 
Table 2. Densities of Ag powders

(a) Conventional Method, (b) New Method

\begin{tabular}{llll}
\hline $\begin{array}{l}\text { Sample } \\
\text { preparation } \\
\text { method }\end{array}$ & $\begin{array}{l}\text { Average particle } \\
\text { size }(\mu \mathrm{m})\end{array}$ & $\begin{array}{l}\text { Specific surface } \\
\text { area }\left(\mathrm{m}^{2} \mathrm{~g}^{-1}\right)\end{array}$ & $\begin{array}{c}\text { Tap density } \\
\left(\mathrm{gcm}^{-3}\right)\end{array}$ \\
\hline & & & \\
(a) & 3.11 & 2.40 & 0.75 \\
(b) & 0.98 & 1.40 & 2.07 \\
\hline
\end{tabular}

真密度に近い単結晶状の粉末を形成したと考えられる.

\section{3 合成粒子の粉体物性}

核成長反応法を用いて合成した $\mathrm{Ag}$ 粒子の粉体特性は, XRDにより測定しそれぞれの半価幅から Holl plotを行い，結 晶子将ズを求めた. 以下にその計算式 $(6) \sim(8)$ を示す.

$$
\begin{aligned}
& \gamma=\gamma_{\mathrm{p}}+\gamma_{\mathrm{s}} \\
& \gamma_{\mathrm{p}}=\left(\mathrm{K} \lambda / D_{\mathrm{p}} \operatorname{COS} \theta\right) \\
& \gamma_{\mathrm{s}}=\eta \tan \theta
\end{aligned}
$$

$\gamma$ : 半価幅, $\gamma_{\mathrm{p}}$ : 結晶子サイズ, $\gamma_{\mathrm{s}}$ : 応力による半価幅, $K$ : 定 数, $\lambda: \mathrm{X}$ 線の波長, $\theta$ : 回折角, $D_{\mathrm{p}}$ : 結晶子サイズ, $\eta$ : 応力, 測定結果より，合成した $\mathrm{Ag}$ 粒子の結晶子サイズは $0.012 \mu \mathrm{m}$ であり通常の硝酸銀水溶液とヒドラジンを還元剤として用いた 同時混合する一般的な湿式化学還元法で合成した $\mathrm{Ag}$ 粒子の結 晶子サイズが $0.005 \mu \mathrm{m}$ 前後であったことに比べてかなり大き いことが分かった。

表 2 に，通常の湿式化学還元法で合成した凝集粒子が多数存 在する従来法の粒子 (a) と本実験による核成長反応法による粒 子(b)のBET 法による比表面積とタップ密度を示す。表 2 よ り明らかなように核成長反応法を用いて合成した $\mathrm{Ag}$ 粒子は, 比表面積加ら真球と仮定して算出した粒径 $0.4 \mu \mathrm{m}$ と図 5 (b)の SEM 写真から求めた粒子の平均粒径 $0.5 \mu \mathrm{m}$ と近似しているこ とから核成長反応法で合成した $\mathrm{Ag}$ 粒子は，単分散性が極めて 高いと言える.

\section{4. 結 論}

積層セラミッタスコンデンサーや誘電体共振器などの精密電 極として使用できる Ag 粉末を湿式還元法で合成することを目 的に単分散粒子の生成機構を史験的に検討した。

また，それらの粉体物性を従来法で合成した $\mathrm{Ag}$ 粒子と比較 検討した，得られた実験結果は，以下のと抢りである。

（1）単分散粒子を生成させるのに重要な因子である還元速
度を低下させるためには合成温度, 凝集緩和剤の添加濃度, 硝 酸銀溶液濃度の 3 要素の制御が重要であった。

（2）核成長反応法を用いることで電極用金属粉としての $\mathrm{Ag}$ 単分散球状粒子の合成が可能になった。 また，粒径も任意 に制御可能であった。

（3）合成した単分散球状 $\mathrm{Ag}$ 粒子は，TEM 観察より結晶 性の高い六角形をしており電子線回折スポットより単結晶体で あった

（4）合成した独立単分散球状 $\mathrm{Ag}$ 粒子は，従来の湿式化学 還元法と比較して分散性, 結晶性に優れていた.

謝辞 帝京科学大学の井上 嘉氏には, 試料の TEM 撮影 をして頂きました。ここに感謝致します。

\section{文献}

1) W. Stober, A. Fink and E. Bohn, J. Colloid Interf. Sci., 26, 62-68 (1968).

2) N. Mizutani, J. Soc. Powder Tech. Japan, 26, 41-43 (1989) [in Japanese].

3) N. Mizutani, Fine Ceram., 23, 3-7 (1990) [in Japanese].

4) T. Ikemoto, K. Uematsu, N. Mizutani and M. Kato, J. Ceram. Soc. Japan (Yogyo-Kyokai-Shi), 93, 261-66 (1985) [in Japanese].

5) T. Ogihara, T. Ikemoto, N. Mizutani and M. Kato, J. Mater. Sci., 21, 2771-75 (1986).

6) T. Ogihara, N. Mizutani and M. Kato, Ceram. Int., 13, 35-39 (1987).

7) T. Ogihara, T. Ikemoto, N. Mizutani and M. Kato, J. Am. Cerem. Soc., 72, 421 (1989).

8) F. Fievet, J. P. Lagier, B. Blin, B. Beaudoin and M. Figlarz, Solid State Ionics, 32/33, 198-205 (1989).

9) C. Ducamp-Sanguesa, R. Herrera-Urbina and M. Figlarz, Solid State Ionics, 63/65, 25-30 (1993).

10) S. Tamir and S. Berger, Thin Solid Films, 276, 108-11 (1996).

11) K. Otuka, J. Soc. Powder Tech. Japan, 27, 754-60 (1990).

12) R. A. Crane, L. C. Chao and R. P. Andres, Mater. Res. Soc. Symp. Proc., Vol. 368 (1995) pp. 127-32.

13) S. Che, O. Sakurai, T. Yasuda, K. Shinozaki and N. Mizutani, J. Ceram. Soc. Japan, 105, 269-71 (1997).

14) S. Hamada, Y. Kudo and T. Tojo, Colloid and Surface, 67, 45-51 (1992).

15) V. K. LaMer and R. H. Dinergar, J. Am. Chem. Soc., 72, 4847 (1950).

16) N. Mizutani and K. Sinozaki, Inorganic Mater., 4, 180-86 (1997).

17) E. Matijevic, Accounts Chem. Res., 14, 22 (1981). 